See discussions, stats, and author profiles for this publication at: https://www.researchgate.net/publication/311505552

\title{
The role of remote sensing in the development of SMART indicators for ecosystem services assessment
}

Article in Biodiversity · December 2016

DOI: $10.1080 / 14888386.2016 .1246384$

CITATIONS

3

3 authors:

Terence P. Dawson

King's College London

150 PUBLICATIONS 13,259 CITATIONS

SEE PROFILE

A Chloe Brown

University of Nottingham

7 PUBLICATIONS 60 CITATIONS

SEE PROFILE
READS

357

University of Dundee

49 PUBLICATIONS 2,311 CITATIONS

SEE PROFILE

Some of the authors of this publication are also working on these related projects:

Displaced communities, environmental degradation and sustainable livelihoods in Uganda View project

Spatio-TEmporal Dynamics of Forest Response to ENSO Drought (STEED) View project 
This is an Accepted Manuscript of an article published by Taylor \& Francis in Biodiversity on $7^{\text {th }}$ December 2016, available online:

http://www.tandfonline.com/doi/abs/10.1080/14888386.2016.1246384

\title{
The role of remote sensing in the development of SMART indicators for ecosystem services assessment.
}

Dawson, T.P. ${ }^{1} *$ Cutler, M.E.J. ${ }^{1}$ and Brown, C. ${ }^{2}$

1. Geography and Environmental Science, School of Social Science, University of Dundee, DD1 4HN, UK.

2. School of Geography, University of Nottingham, Nottingham, NG7 2RD.

* Email contact: t.p.dawson@dundee.ac.uk

\begin{abstract}
Human beings benefit from a wide range of goods and services from the natural environment that are collectively known as ecosystem services. However, rapid natural habitat loss, overexploitation and climate change is causing accelerating losses of populations and species, with largely unknown consequences on ecosystem functioning and the sustainable provision of ecosystem services. It is crucial, therefore, to develop a suite of indicators of the health and status of ecosystems, to monitor and quantify services delivery and to facilitate policy responses to stop and reverse negative trends. An effective framework to facilitate the development of suitable indicators is by using the SMART approach, which defines five criteria that could be applied to set monitoring and management goals, which are Specific, Measurable, Achievable, Realistic and Time-sensitive. Remote Sensing provides a useful data source that can monitor ecosystems over multiple spatial and temporal scales. Although the development and application of landscape indicators (vegetation indices, for example) derived from remote sensing data are comparatively advanced, it is acknowledged that a number of organisms and ecosystem processes are not detectable by remote sensing. This paper explores several approaches to overcome this limitation, by examining the strong affinity of species with dominant habitat structures and through the coupling of remote sensing and ecosystem process models using examples drawn from a number of important ecosystems.
\end{abstract}

Key words: Earth Observation, ecosystem services, biomass, carbon, degradation, peatlands. 


\section{Introduction}

The health and well-being of Human beings benefit directly or indirectly from a wide range of goods and services from the natural environment that can be grouped into four main categories: Provisioning services, such as food, fibre, energy and water; Regulating services, such as such as climate regulation, water purification and flood protection; Cultural services, which have recreation and aesthetic value, for example, and; Supporting services, which underpin the provision of the other services categories (MEA, 2005). Collectively known as ecosystem services, many of these processes or structures arising from the interaction between living organisms and their physical habitats are fundamental to human well-being. All natural habitats produce a wide range of different ecosystem services providing benefits at multiple temporal and spatial scales, with some examples presented in Table 1. However, habitat loss and fragmentation (Brooks et al., 2002; Watson et al., 2004), pollution (especially excessive nutrient loading), overexploitation and climate change impacts on ecosystems as well as the synergistic effects of multiple drivers (Brook et al., 2008) is resulting in accelerating losses of populations and species, with largely unknown consequences on the sustainable provision of ecosystem services. Whilst a number of recent studies have attempted to construct conceptual models of the interactions between species, ecosystems and human processes that modify (either deliberately or unintended) ecosystems functions that generate goods and services (Rounsevell et al., 2010), the dynamics of social-ecological systems (SES) are complex (Dawson et al., 2010). As a result, it remains difficult to assess and quantify the extent and abundance of species or habitat type necessary to maintain sufficient levels of ecosystem services to support human well-being in a sustainable manner (Luck et al., 2009). It is crucial, therefore, to develop a suite of indicators of the health and status of ecosystems, to monitor and quantify services delivery and to facilitate policy responses to stop and reverse negative trends (Feld et al., 2010). An effective framework to facilitate the development of suitable indicators is through using the SMART approach, which defines five criteria that could be applied to set management goals, which are Specific, Measurable, Achievable, Realistic and Time-sensitive (Shahin and Mahbod, 2007). For ecosystem management objectives, remote sensing provides a useful data source that can monitor ecosystems over multiple spatial and temporal scales and that complies with the SMART criteria. Although the development and application of landscape indicators (vegetation indices, for example) derived from remote sensing data are comparatively advanced and operational for a number of environmental monitoring activities, it is acknowledged that a number of organisms and ecosystem processes are not detectable by remote sensing. However, there has been increasing use of high-resolution hyperspectral and hyper-spatial imagery from airborne and satellite-borne sensors for delineating individual tree canopies and identifying vegetation species (e.g. Sarrazin et al., 2011; Mehner et al., 2004). Remote sensing has also been used to detect and map impacts from invasive plant species that can have negative consequences for biodiversity and ecosystem function (Henderson \& Dawson, 2009). Large mammals and herbivores including elephants, wildebeest and zebra have been monitored with remote sensing, either directly mapped from high spatial resolution data (Zheng, 2012) or the presence of species inferred from characteristic disturbance such as burrows (Löffler and Margules 1980). Given the ever greater spatial and spectral resolution of airborne and satellite sensors, we can expect to see more publications in this area. Indeed, the plethora of new sensors and remote sensing technologies that are likely to become available in the near future suggest the potential to estimate and map critical ecosystem indicators at local to regional scales will become ever more common and robust (Pettorelli et al., 2016). This paper outlines some research in progress and presents some examples of indicators that are derived from remote sensing to monitor important ecosystems and highlights a number of challenges and limitations that remain outstanding. 


\section{Developing Indicators for Ecosystem Service Monitoring}

One of the main challenges in ecosystem monitoring remains the development of suitable direct indicators, i.e. indicators that directly refer to the component of biodiversity or to the functions and processes behind a certain ecosystem service. Scientists often discover that certain ecosystem services are provided by a small number of species or a functional group of species rather than by the whole diversity present in that ecosystem (Luck et al. 2009). Feld et al. (2010) have defined seven criteria to assess the general suitability of existing indicators of biodiversity and ecosystem services (Table 2). These criteria provide a checklist for indicator development and testing, which, if applied consistently, can help assist the development and application of indicators of biological relevance across multiple spatial scales. Of particular interest to the Earth Observation community is the seventh criterion, which addresses the applicability of remote sensing to obtain the required data for indication.

Remote sensing data (for deriving knowledge about ecosystem and habitat area, vegetation status, degree of fragmentation, etc) can provide a generalised comparable data source (EEA 2007). Satellite images are available at regional to global scales and across multiple time-scales. Satellite-derived remote-sensing indicators, such as vegetation indices, enable us to compare and scale-up data measured from fieldwork to multiple spatial scales. Indicators that are based upon remote sensing data allow for cross-comparisons of biodiversity and ecosystem services at comparatively broad scales and across different ecosystems (Nagendra 2001; Duro et al. 2007).

The development and the application of landscape indicators derived from remote sensing data are comparatively advanced (e.g., Gobin et al. 2004; EEA 2007) and some examples are provided (Table 3). The Normalised Difference Vegetation Index (NDVI; Tucker 1979), for instance, constitutes a well-described and widely applied indicator of green leaf biomass, which has been used to estimate changes in vegetation health, leaf area and forest canopy cover from landscape to global scales (e.g. Ares et al. 2001; Ingram and Dawson 2005). In a systematic review of the use of remotely sensed data in ecosystem service assessments, it was noted by de Araujo-Barbosa et al., (2015) that maps of land cover and NDVI were the most commonly used remote sensing-derived products among all ecosystem services categories.

It is acknowledged that a number of organisms not detectable by remote sensing have a strong affinity with a dominant species that creates and maintains large-area physical structures over long (including evolutionary) time periods. For example, sphagnum bogs, wetlands, savannas, salt marshes and coral reefs create habitats that provide food sources, micro-environments and protection for a whole community of species that have specificity to these habitat types (see, for example, Jones et al., 1994). The identification and classification of these macro structures by remote sensing is possible (e.g., Yang and Prince 2000; Ozesmi and Bauer 2002; Silvestri et al. 2003; Mumby et al. 2004; Harris and Bryant 2009) and quantitative assessments of biodiversity populations have also been made using the species-area relationship and extent of habitat derived from remote sensing (Turner et al. 2003; Jha et al. 2005). Other examples of the link between specific species and landscape indicators have been reported by Dormann et al. (2007) and Hendrickx et al. (2007). However, a reliable indication of the status and trends of biodiversity and ecosystem service provision beyond habitat mapping and based on remote sensing data, requires more research effort to validate the results. This in particular applies to the validation of statistically significant relationships of landscape metrics and measures of components of biodiversity by ground-based observations. The knowledge of these relationships at the landscape scale might provide a widely applicable and cost-effective tool for biodiversity monitoring (Lengyel et al. 2008). 
Clearly the potential of remote sensing as a source of information to obtain information relating to the provision of ecosystem services and indicators of ecosystem status is promising, and several authors have produced useful reviews illustrating this (e.g. Pettorelli et al., 2016; de Araujo Barbosa et al., 2015), and more particularly potential opportunities for applied ecology (Pettorelli et al., 2014) and as a tool for monitoring progress towards biodiversity targets (O'Connor et al., 2015). Here we examine three case studies drawn from the authors own research that have utilised Earth Observation techniques over a range of temporal and spatial scales to illustrate the development of explicit linkages between ecosystem services and remote sensing indicators that adhere to the SMART concept. The examples illustrate the use of both passive and active remote sensing systems, and whilst they are applied at the landscape scale, they are also applicable at the global scale. The three examples have been deliberately chosen as they make use of existing data that are widely available and commonly used. The potential of new sensors and remote sensing technologies are then discussed in the Discussion section, highlighting the enormous current potential in this arena.

\section{Case studies}

\section{(i) Forests, carbon storage and provisioning services}

Tropical forests play critical roles in the functioning of our planet and the maintenance of life (Myers, 1996). They serve as regulators of global and regional climate systems (Gedney \& Valdes, 2000), act as carbon sinks (Grace et al., 1995), are rich in biodiversity (Wilson, 1988), provide valuable ecosystem services, and serve as vital resources for human populations (Laurance, 1999). Thus, monitoring the state and condition of tropical forests can also provide indications of the health of our planet and its inhabitants. In southeast Madagascar, the coastal littoral forests have been identified as a national conservation priority (Ganzhorn et al. 2001) due to the concentrations of national and local endemic plant species, a diverse tree flora (Dumetz 1999), and high diversity of faunal taxa (Ganzhorn 1998; Ramananmanjato 2000; Watson et al. 2004). The forests also provide important ecological services for local communities, including food, energy, medicines and construction materials. Indeed, for many of the rural poor, these forests act as a critical safety net during times of shock, for example, crop failure arising from extreme climate events, such as drought or during seasonally 'lean' periods. Assessing the sustainability of forest resource use requires resolving appropriate spatial and temporal scales for establishing a baseline assessment. Ingram and colleagues (Ingram and Dawson, 2005a, 2005b; Ingram et al., 2005a, 2005b) undertook a synthesis of remote sensing techniques at multiple spatial and temporal scales combined with climatic data and information collected during ecological field surveys within a SES framework analysis to evaluate natural and anthropogenic processes acting upon littoral forest ecosystems in south eastern Madagascar. The provenance and temporality of the drivers and pressures of environmental change acting upon these forests are quite diverse, including natural climate change (both chronic and transient, including drought and cyclones) with human pressures on the system including processes such as logging for fuel-wood or construction purposes by local people or forest clearance (for charcoal-making) by itinerant groups of people. The long-term selective use of forest resources are chronic in nature whereas a large-scale forest clearance event would be transient. Both types of events can negatively affect both ecosystem functioning and biodiversity, which may compromise the ability of the natural forest system to provide essential ecological goods such as fuel-wood, wild food, medicines and/or vital ecological services such as soil stabilization for erosion prevention, windbreaks or water filtration. The project established fixed plots in several of the fragments; to determine plant and tree species composition and to provide Diameter at Breast Height $(\mathrm{DBH})$ measurements for validation of a satellite-derived degradation map (Figure 1) (Ingram et al., 2005a). They used an artificial neural network (ANN) to predict basal area from radiance values in Landsat TM bands 3, 4, 5 and 7 to produce a predictive map of basal area for the entire forest landscape. The ANNs produced strong and significant relationships between predicted 
and actual measures of basal area using a jackknife method $(\mathrm{r}=0.79, \mathrm{pb} 0.01)$ and when using a larger data set $(\mathrm{r}=0.82, \mathrm{pb} 0.01)$. The map of predicted basal area produced by the ANN was assessed in relation to a pre-existing map of forest condition derived from a semi-quantitative field assessment. The predictive map of basal area provided finer detail on stand structural heterogeneity, captured known climatic influences on forest structure and displayed trends of basal area associated with degree of human accessibility. The inventories confirmed the importance of the majority (>84\%) of the tree species as being of utilitarian value to the local communities (Figure 2) (Ingram et al., 2005b). The primary usages of tree species identified were energy provision (firewood and charcoal), construction materials, medicine, spiritual purposes, food, fibres and oil. This study demonstrated that forest structural features, such as basal area and stem density, known to indicate human impact or disturbance, can be related to species richness for utilitarian species. The high abundance, high basal area, and promising regeneration potential of highly exploited utilitarian species across the landscape indicates that these forests have significant value for human well-being, which has not been irreversibly lost despite long-term human pressure on these systems.

\section{Synthetic Aperture Radar for estimating biomass and carbon content in forest plantations}

Synthetic Aperture Radar (SAR) provides a viable method for monitoring forests' resources at regional and national scales and for estimating carbon stocks. The microwave radiation used by SAR is of sufficiently long wavelengths not to be significantly affected by atmospheric attenuation, resulting in an operating capability which is independent of cloud cover. Importantly, microwave interactions are sensitive to the roughness and physical geometry of forests, an asset which, when combined with the ability of the radiation to penetrate forest canopies, results in the sensitivity of SAR backscatter to key biophysical variables, such as tree density and above ground biomass (Beaudoin et al., 1994; Baker et al., 1994; Green et al., 1996, Green, 1998; Cutler et al., 2012). The sensitivity of radar backscatter to above-ground biomass density is both wavelength and polarization dependent. This relates to the depth of penetration of different wavelengths, typically concentrating on the dominance of volume (canopy) scattering in X-band $(3 \mathrm{~cm})$ and C-band $(5 \mathrm{~cm})$ in contrast to branch scattering at $23 \mathrm{~cm}$ (L-band) and trunk-ground interactions at P-band $(50 \mathrm{~cm}$ ) (Ranson and Sun, 1994). Whereas short wavelength $X$ - and C-band backscatter is sensitive mainly to canopy architecture (e.g. Green, 1998), it is the longer wavelength L- and P-band backscatter that is highly correlated with forest above-ground biomass density. As Baker et al. (1994) also demonstrated, the cross-polarized term is often most strongly correlated with forest biomass density. Relationships between backscatter and biomass density are characterized by a saturation of the radar signal before reaching high bole volume (Imhoff, 1995). Dobson et al. (1992) analysed radar responses at L-, P- and C-band to forest biomass density and found an approximately linear response of backscatter with increasing biomass density with wavelength dependent saturation levels around $200 \mathrm{t}$ ha-1 for P-band and $100 \mathrm{t}$ ha-1 for L-band. In the study of Imhoff (1995) saturation was reached at $100 \mathrm{t}$ ha-1 for P-, $40 \mathrm{t}$ ha- 1 for L- and $20 \mathrm{t}$ ha- 1 for C-band in coniferous and broadleaf evergreen forests. The accuracy with which biophysical parameters can be retrieved from SAR measurements of forests depends considerably upon vegetation structure and ground conditions. Thetford Forest is a Forestry Commission plantation in East Anglia, UK created from heathland early this century with an ongoing programme of crop rotation and a long history of experimental planting which provide both a large variety of tree species and a wide range of tree ages within the primary crop which is Corsican Pine (pinus negra). The minimal topographic variation, long management history and previous use as a remote sensing 'supersite' combine to make this an ideal site for remote sensing analysis of carbon stocks. Extensive fieldwork was carried out at Thetford in 1989 in order to quantify the above-ground biomass density in selected forest stands. A range of biomass densities were characterized at both sites with measurements of tree height, DBH and species. In addition, stand partition information on tree 
species and planting date were digitised from forest management maps in order to extrapolate the field measurements over a greater number of forest stands (Luckman and Baker, 1997). The biomass density was estimated by forming a regression between stand age and the measured biomass density and extrapolating to a large number of stands for which the planting date was provided by the UK Forestry Commission. SAR data used in this early study were L-band polarimetric AIRSAR data from Thetford acquired during the NASA/JPL 1991 MAC-Europe campaign. The relationship between estimated above-ground biomass density and backscattering coefficient shows a reasonable dynamic range with saturation occurring at a stand biomass density of between 60-80 tonnes per hectare (Figure 3). Many authors have since gone on to test the relationships between SAR backscatter coefficient and biomass in different forest types, stocking densities and biomass ranges, and clearly show the value of SAR for deriving indicators of forest status, extent, degradation and fragmentation.

\section{(iii) Assessment of peatland habitat, degradation and erosion}

Whilst much research has focussed on forests as providers of important ecosystem services, less focus has been directed towards organic soils, and in particular areas of extensive organic soils such as peatlands. These are of high conservation value, not only for their intrinsic habitat value, but also because they offer a wide range of ecosystem services (Table 1), including water supply, recreation, biodiversity, carbon sequestration and storage (Evans and Lindsay, 2010). However, physical degradation of peatlands is widespread, particularly in the UK, and new methods for assessing the status of these environments is required to best regulate erosion and help manage regeneration.

Remote sensing has often been suggested as a means for providing indicators of peatland degradation as an alternative to field-based methods that often rely on the subjective interpretation of the landscape, with varying degrees of agreement (Cherrill and McClean, 1999). However, the successful application of remote sensing for peatland mapping has been limited thus far, due in part to the spatial resolution of available data from broad-band satellite sensors (e.g. Landsat Thematic Mapper with a spatial resolution of $30 \mathrm{~m}$ ). The intrinsic scale of peatland features in the UK tend to be smaller than $30 \mathrm{~m}$ (e.g. patches of bare peat, pool systems, etc.), and satellite sensors have proved inadequate to provide high quality peatland habitat maps at appropriate scales (McMorrow and Hume, 1986). As a result, remote sensing has rarely been used to inform erosion regulation in these environments, often limited to manual interpretation of peatland habitats from aerial photography.

Recently, however, a number of high spatial resolution satellite sensors have been launched which provide multispectral observations suitable for automated land cover mapping and feature extraction (e.g. WorldView series of satellite). These typically have spatial resolutions of between 4 and $0.5 \mathrm{~m}$, often exceeding the minimum $3.45 \mathrm{~m}$ spatial resolution required for peatland habitat mapping suggested by Cole et al. (2014). Indeed, such sensors have already been used to map upland vegetation species, providing accuracies in excess of those achieved with field-based methods (Mehner et al., 2004; Mills et al., 2006).

To explore this new opportunity a WorldView-2 image was acquired for an area of northern Scotland, owned and managed by Wildland Ltd. The image has a spatial resolution of $1.85 \mathrm{~m}$ for the multispectral data ( 8 wavebands located in the visible and near infrared) and $0.46 \mathrm{~m}$ in the panchromatic, and was used to map indicators of peatland status, including the extent of specific land cover classes, such areas of bare peat and vegetation associated with disturbance, and mapping expressions of physical disturbance associated with fires, peat cutting and drainage. To make the most of the high frequency textural information in the panchromatic image, the data were pansharpened before deriving a map of land cover using a standard supervised maximum likelihood algorithm. Thirteen classes were mapped and the resulting image was assessed as having an overall 
accuracy of $89 \%$. Additionally, the presence or absence of linear features in mire and bare peat land cover classes were extracted using an analysis of image texture. After extracting information for single classes, such as bare peat (figure 4), the area was then segmented into $1 \mathrm{~km}^{2}$ grid cells and the mean size and density of land cover patches in each cell determined using the FRAGSTATS software, thus providing an indication of habitat fragmentation and degradation severity in different parts of the estate (Figure 5). To help inform management and possible restoration of the site, the remote sensingderived land cover and feature data, along with a digital elevation model, were used to derive an assessment of erosion risk. Using a knowledge-based classifier, a rule-base was developed to combine information indicating areas of high potential peat erosion. For example, areas of bare peat that occurred on slopes or were hydrologically or fragmentally connected to an area of disturbance were deemed of high risk of erosion (Evans and Lyndsay 2010), whereas intact areas of mire that exhibited no pools or patches of bare peat where deemed at less risk (Figure 6). Whilst further work is required to determine the applicability of these methods to other sites, the work highlights the potential of remote sensing for providing indicators of peatland fragmentation, connectivity, extent and erosion.

\section{Discussion}

The three case studies described above provide a snapshot of the application of existing remote sensing datasets and methods applied to derive landscape indicators of biodiversity and the status and provision of ecosystem services. However, as alluded to in the introduction of this paper, we stand on the cusp of a significant change in the provision of remotely sensed data. The plethora of new satellite and airborne sensors now in operation or due for launch shortly (Table 4) represent a step change in both quantity and access to data. In addition, by exploiting information from new technologies such as hyperspectral remote sensing and terrestrial laser scanning, it should be possible to derive additional landscape indicators that conform to the SMART approach.

As an example of this, and in relation to the peatland example described above, new remote sensing methods have already been used to estimate a number of critical ecosystem variables, such as upland vegetation biochemistry and phenology (e.g. Cole et al., 2014), moisture stress, sphagnum distribution (e.g. Harris and Bryant, 2009), fine scale hydrological networks can be extracted (e.g. Korpela et al., 2009; Anderson et al., 2010) and peat physico-chemical properties (e.g. McMorrow et al., 2004). The latter example, in particular, demonstrates the potential of hyperspectral sensors for assessing potential future erosion. The physico-chemical properties of peat, especially the degree of humification, expresses the spatial severity and risk of further erosion. Loss of the top, woody, more resistant layer (acrotelm) with its high hydraulic conductivity means removal of the major pathway for subsurface lateral drainage (Burt et al., 1997) and easier subsequent erosion of the less resistant sub-surface layers. McMorrow et al., (2004) were able to use data from a hyperspectral airborne sensor to map variation in the degree of humification of exposed peat in the southern Pennines, UK, providing indicators to inform future management and restoration. Thus, with the availability of high-spatial resolution satellite data and the development of hyperspectral and laser technologies, it is clear that remote sensing methods will play a critical role in regulating and managing peatlands, and the ecosystem services they provide.

However, for any application there remains challenges in the application of these new datasets to derive landscape indicators. For example, the scale-dependency of observations of landscape indicators and functionally relevant ecosystem processes in relation to the spatial resolutions now available from remote sensing requires investigation. Additionally, further work needs to focus on the applicability and repeatability of methods and relationships developed for one sensor and / or site, to other sensors, sites and landscape situations (e.g. Cutler et al., 2012). 
To address this, there has been considerable recent focus on the development and use of standardised remotely sensed-products (Andrew et al., 2014; Seppelt et al., 2011). These products, which are largely land cover/land use type products but also include NDVI and other remotely sensed variables, tend to be produced from a single satellite sensor, removing variability associated with multiple sensor characteristics. Additionally, products may be single-year or multi-year products (e.g. European Space Agency's Climate Change Initiative Land Cover Products), enabling change to be detected using a standardised set of data characteristics or land cover classes. Thus the use of a standardised product may reduce some of the uncertainty associated with individuals deriving landscape indicator assessments themselves. However, the uptake in use of such products has been slow, put down partly to a lack of awareness but also a lack of confidence in spatial accuracy (Congalton et al., 2014). Most operational products are still restricted to spatial resolutions of between $1-5 \mathrm{~km}$, which whilst providing frequent temporal updates may be a deterrent toward their use for some applications. There also remains additional problems of reconciling different definitions of ecological variables and land cover classes from one product to another.

Despite these challenges, the real value of remote sensing indicators to provide consistent and coherent information on the state of the Earth's ecosystems over multiple spatial and temporal scales, is paramount. Given the rapidly growing World population creating unprecedented demands and pressures on our natural resources, using the near real-time benefits of this technology for monitoring ecosystem changes is essential.

\section{Conclusion}

Although remote sensing provides the potential for the establishment of indicators for continuous monitoring and assessment of ecosystem services over multiple spatial scales, in many cases they provide only an indirect measure of the biodiversity and ecosystem function and process of interest. Research in progress to improve upon this situation includes the coupling of remote sensing data to ecosystem process simulation models (to estimate water and carbon exchange between the biosphere and the atmosphere, for example) or the use of species-area relationships to assess individual species populations. Although it is unlikely that remote sensing will supply all the necessary indicators for the assessment and monitoring of ecosystem services, remote sensing data has considerable advantages over other indicator data sources due to its SMART compliance. With the development of new technologies and methods for exploiting information in remotely sensed data, such as illustrated in the case studies described here, it is clear that the role of remote sensing in ecosystem services assessment and monitoring is going to become more extensive, both in spatial terms but also in the types of critical ecosystem variables that can be retrieved.

\section{Acknowledgements}

Wildand Ltd (with assistance from Scottish Natural Heritage) provided financial and logistical support for the assessment of peatland degradation in northern Scotland. Additionally we thank the anonymous reviewers for their encouraging comments and suggestions for the improvement of this manuscript. 


\section{References}

de Araujo Barbosa, C.C., Atkinson, P.M. and Dearing, J.A., 2015, Remote sensing of ecosystem services: a systematic review. Ecological Indicators, 52, 430-443.

Anderson, K., Bennie, J. and Wetherelt, A., 2009, Laser scanning of fine scale pattern along a hydrological gradient in a peatland ecosystem. Landscape Ecology, 25, 477-492.

Anderson, K., Bennie, J., Milton, E.J., Huighes, P.D.M., Lindsay, R. and Meade, R., 2010, Combining LiDAR and IKONOS data for eco-hydrological classification of an ombotrophic peatland. Journal of Environmental Quality, 39, 260-273.

Andrew, M.E., Wulder, M.A. and Nelson, T.A., 2014, Potential contributions of remote sensing to ecosystem service assessments. Progress in Physical Geography, 38, 328-353.

Ares, J., Bertiller, M. and del Valle, H., 2001, Functional and structural landscape indicators of intensification; resilience and resistance in agroecosystems in southern Argentina based on remotely sensed data, Landscape Ecology, 16:221-234.

Balzter, H., Skinner, L., Luckman, A., and Brooke, R. (2003): Estimation of tree growth in a conifer plantation over nineteen years from multi-satellite L-band SAR. Remote Sensing of Environment 84: 184-191.

Baker, J.R., Mitchell, P.L., Cordey, R.A., Groom, G.B., Settle, J.J. and Stileman, M.R., 1994, Relationships between physical characteristics and polarimetric radar backscatter for Corsican pine stands in Thetford Forest, UK, International Journal of Remote Sensing 15: 2827-2849.

Beaudoin, A., Le Toan, T., Goze, S., Nezry, E., Lopes, A., Mougin, E., Hsu, C.C., Han, H.C., Kong, J.A. and Shin, R.T., 1994, Retrieval of forest biomass from SAR data, International Journal of Remote Sensing 15: 2777-2796.

Billeter, R., Liira, J., Bailey, D., Bugter, R., Arens, P., Augenstein, I., Aviron, S., Baudry, J., Bukacek, R., Burel, F., Cerny, M., De Blust, G., de Cock, R., Diekoetter, T., Dietz, H., Dirksen, J., Dormann, C., Durka, W., Frenzel, M., Hamersky, R., Hendrickx, F., Herzog, F., Klotz, S., Koolstra, B., Lausch, A., Le Coeur, D., Maelfait, J. P., Opdam, P., Roubalova, M., Schermann, A., Schermann, N., Schmidt, T., Schweiger, O., Smulders, M. J. M., Speelmans, M., Simova, P., Verboom, J., van Wingerden, W. K. R. E., Zobel, M. and Edwards, P. J., 2008, Indicators for biodiversity in agricultural landscapes: a pan-European study, Journal of Applied Ecology, 45:141-150.

Brook, B.W.; Sodhi, N.S. \& Bradshaw, C.J.A., 2008, Synergies among extinction drivers under global change. Trends in Ecology and Evolution 25: 453-460

Brooks, T.M., Mittermeier, R.A., Mittermeier, C.G., da Fonseca, G.A.B., Rylands, A.B., Konstant, W.R., Flick, P., Pilgrim, J., et al., 2002, Habitat loss and extinction in the hotspots of biodiversity. Conservation Biology, 16, 909-923.

Burt, T., Labadz, J., and Butcher, D., 1997, The hydrology and fluvial geomorphology of blanket peat: implications for integrated catchment management. In Blanket Mire Degradation: Causes, 
Consequences and Challenges, edited by J.H. Tallis, R. Meade and P.D. Hulme (Aberdeen: Macaulay Land Use Research Institute), pp. 121-127.

Cherril, A. J., and McClean, C., 1999, The reliability of 'phase1' habitat mapping in the UK: The extent and types of observer bias. Landscape and Urban Planning, 45, 131-143.

Cole, B., McMorrow, J. and Evans, M., 2014, Spectral monitoring of moorland plant phenology to identify a window for hyperspectral remote sensing of peatland. ISPRS Journal of Photogrammetry \& Remote Sensing, 90, 49-58.

Congalton, R.G., Jianyu, G., Yadav, K., Thenkabail, P. and Ozdogan, M., 2014, Global land cover mapping: a review and uncertainty analysis. Remote Sensing, 6, 12070-12093.

Cutler, M.E.J., Boyd, D.S., Foody, G.M. and Vetrivel, A., 2012, Estimating tropical forest biomass with a combination of SAR image texture and Landsat TM data: an assessment of predictions between regions. ISPRS Journal of Photogrammetry and Remote Sensing 70: 66-77.

Dawson, T.P., Rounsevell, M.D.A., Kluvánková-Oravská, T., Chobotová, V. and Stirling, A., 2010, Dynamic properties of complex adaptive ecosystems: implications for the sustainability of service provision, Biodiversity and Conservation 19 (10), 2843-2853.

Dormann, C. F, Schweiger, O., Augenstein, I., Bailey, D., Billeter, R., De Blust, G., DeFilippi, R., Frenzel, M., Hendrickx, F., Herzog, F., Klotz, S., Liira, J., Maelfait, J.P., Schmidt, T., Speelmans, M., van Wingerden, W. K. R. E. and Zobel, M., 2007, Effects of landscape structure and land-use intensity on similarity of plant and animal communities, Global Ecology and Biogeography, 16(6):774-787.

Dumetz, N., 1999, High plant density of lowland rainforest vestiges in eastern Madagascar. Biodiversity and Conservation 8: 273-315.

Duro, D.C., Coops, N.C., Wulder, M.A. and HAN, T., 2007, Development of a large area biodiversity monitoring system driven by remote sensing, Progress in Physical Geography, 31: 235-260.

EEA (European Environment Agency), 2007, Halting the loss of biodiversity by 2010: Proposal for a first set of indicators to monitor progress in Europe, EEA Technical Report 11/2007, (Office for Official Publications of the European Communities. Luxembourg), pp. 1-38.

Evans, M. and Lindsay, J., 2010, High resolution quantification of gully erosion in upland peatlands at the landscape scale. Earth Surface Processes and Landforms, 35, 876-886.

Feld, C.K., Sousa, J.P., Martins, d.a., Silva, P. and Dawson, T.P., 2010, Indicators for biodiversity and ecosystem services: towards an improved framework for ecosystems assessment, Biodiversity and Conservation, 19: 2895-2919.

Ganzhorn, J. B. 1998. Nested patterns of species composition and its implications for lemur biogeography in Madagascar. Folia Primatologica 69: 332-341.

Ganzhorn JU, Lowry P, Schatz GE, Sommer S. 2001. The biodiversity of Madagascar: one of the world's hottest hotspots on its way out. Oryx 35: $346-348$. 
Gedney, N., \& Valdes, P. J., 2000, The effect of deforestation on the northern hemisphere circulation and climate. Geophysical Research Letters 27: 3053- 3056.

Gobin, A., Jones, R., Kirkby, M., Campling, P., Govers, G., Kosmas, C. and Gentile, A. R., 2004, Indicators for pan-European assessment and monitoring of soil erosion by water, Environmental Science and Policy, 7:25-38.

Grace, J., Lloyd, J., McIntyre, J., Miranda, A. C., Meir, P., Miranda, H.S., et al., 1995, Carbon-dioxide uptake by an undisturbed tropical rain-forest in southwest Amazonia, 1992 to 1993. Science 270: 778780.

Green, R.M., Lucas, N.S., Curran, P.J. and Foody, G.M. (1996) Coupling remotely sensed data to an ecosystem simulation model - an example involving a coniferous plantation in upland Wales. Global Ecology and Biogeography Letters 5: 192-205.

Green, R.M., 1998a, Relationships between polarmetric SAR backscatter and forest canopy and subcanopy biophysical properties, International Journal of Remote Sensing 19: 2395-2412.

Green, R.M., 1998b, The sensitivity of SAR backscatter to windthrow gaps. International Journal of Remote Sensing 19: 2419-2425.

Harris, A. and Bryant, R.G., 2009, A multi-scale remote sensing approach for monitoring northern peatland hydrology: Present possibilities and future challenges, Journal of Environmental Management, 90:2178-2188.

Henderson, S.J. and Dawson, T.P. (2009) Alien invasions from space: detecting feral goat depredation in the Galapagos Islands using AVHRR, International Journal of Remote Sensing 30 (2), 423-433.

Hendrickx, F., Maelfait, J.P., van Wingerden, W., Schweiger, O., Billeter, R., Speelmans, M., Augenstein, I., Aviron, S., Bailey, D., Bukacek, R., Diekötter, T., Dirksen, J., Herzog, F., Liira, J., Roubalova, M., Vandomme, V. and Bugter, R., 2007, How landscape structure, land use intensity and habitat diversity affect components of arthropod diversity in agricultural landscapes, Journal of Applied Ecology, 44:340-351.

Ingram, J.C. and Dawson, T.P., 2005a, Inter-annual analysis of deforestation hotspots in Madagascar from high temporal resolution satellite observations, International Journal of Remote Sensing, 26:1447-1461.

Ingram, J.C. and Dawson, T. P. 2005b. Climate change impacts and vegetation response on the island of Madagascar. Philosophical Transactions of the Royal Society A 363: 55-59

Ingram, J.C., Dawson, T.P., Whittaker, R.J. 2005a. Mapping tropical forest structure in south-eastern Madagascar using remote sensing and artificial neural networks. Remote Sensing of the Environment 94: 491- 507.

Ingram, J.C., Whittaker, R.J., Dawson, T.P. 2005b, Tree structure and diversity in human-impacted littoral forests, Madagascar. Environmental Management 35: 779-798. 
Imhoff, M.L., 1995, A Theoretical-Analysis of the Effect of Forest Structure On Synthetic-Aperture Radar Backscatter and the Remote-Sensing of Biomass, IEEE Transactions On Geoscience and Remote Sensing 33: 341-352.

Jha, C.S., Goparaju, L., Tripathi, A., Guarai, B., Raghubanshi, A.S., and Singh, J.S., 2005, Forest fragmentation and its impact on species diversity: an analysis using remote sensing and GIS, Biodiversity and Conservation, 14: 1681-1698.

Jones, C.G., Lawton, J.H. and Shachak, M., 1994, Organisms as ecosystem engineers, Oikos, 69: 373386.

Korpela, I., Koskinen, M., Vasander, H., Holopainen, M. and Minkkinen, K., 2009, Airborne small footprint discrete-return LiDAR data in the assessment of boreal mire surface patterns, vegetation, and habitats. Forest Ecology and Management, 258, 1549-1566.

Laurance, W. F., 1999, Reflections on the tropical deforestation crisis. Biological Conservation 91: 109-117.

Lengyel, S., Déri, E., Varga, Z., Horváth, R., Tóthmérész, B., Henry, P-Y., Kobler, A., Kutnar, L., Babij, V., Seliškar, A., Christia, C., Papastergiadou, E., Gruber, B. and Henle, K., 2008, Habitat monitoring in Europe: a description of current practices, Biodiversity and Conservation, 17:33273339.

Löffler, E. and Margules, C., 1980, Wombats detected from space, Remote Sensing of Environment, 9 (1), 47-56.

Luck, G.W., Harrington, R., Harrison, P.A., Kremen, C., Berry, P.M., Bugter, R., Dawson, T.P., de Bello, F., Díaz, S., Feld, C.K., Haslett, J.R., Hering, D., Kontogianni, A., Lavorel, S, Rounsevell, R., Samways, M.J., Sandin, L., Settele, J., Sykes, M.T., van den Hove, S., Vandewalle, M. and Zobel, M., 2009, Quantifying the Contribution of Organisms to the Provision of Ecosystem Services, Bioscience, 59:223-235.

McMorrow, J. M. and Hume E., 1986, Problems of applying multispectral classification to upland vegetation. International Archives Photogrammetry \& Remote Sensing, 26, 610-620.

McMorrow, J., Cutler, M.E.J., Evans, M. and Al-Roichdi, A., 2004, Towards hyperspectral indices of the composition of peat. International Journal of Remote sensing, 25, 313-325.

MEA (Millennium Ecosystem Assessment), 2005, Ecosystems and Human Well-being: Synthesis (Island Press, Washington DC), pp. 1-137.

Mehner, H., Cutler, M. E. J. and Fairbairn, D., 2004, Remote sensing of upland vegetation: the potential of high spatial resolution satellite sensors. Global Ecology and Biogeography, 13, 359-369.

Mills, H., Cutler, M.E.J. and Fairbairn, D., 2006, Artificial Neural Networks for multi-site classifications of upland vegetation. International Journal of Remote Sensing, 27, 2177-2195.

Mumby, P.J., Skirving, W., Strong, A.E., Hardy, J.T., LeDrew, E.F., Hochberg, E.J., Stumpf, R.P. and David, L.T., 2004, Remote sensing of coral reefs and their physical environment, Marine Pollution Bulletin, 48:219-228. 
Myers, N., 1996, The world's forests: Problems and potentials. Environmental Conservation 23: 156168.

Myers, N., Mittermeier, R. A., Mittermeier, C., Fonseca, G., \& Kent, J., 2000, Biodiversity hotspots for conservation priorities. Nature 403: 853-859.

Nagendra. H., 2001, Review article, Using remote sensing to assess biodiversity, International Journal of Remote Sensing, 22:2377-2400.

O'Connor, B., Secades, C., Penner, J., Sonnenschein, R., Skidmore, A., Burgess, N.D., Hutton, J.M., 2015, Earth observation as a tool for tracking progress towards the Aichi biodiversity targets. Remote Sensing in Ecology and Conservation, 1: 19-28.

Ozesmi, S.L. and Bauer, M.E., 2002, Satellite remote sensing of wetlands, Wetlands Ecology and Management, 10:381-402.

Pettorelli, N., Safi, K., Turner, W., 2014, Satellite remote sensing, biodiversity research and conservation of the future. Philosophical Transactions of the Royal Society, 369: 20130190; DOI: 10.1098/rstb.2013.0190.

Pettorelli, N., Wegmann, M., Skidmore, A., Mücher, S., Dawson, T.P. et al., 2016, Framing the concept of satellite remote sensing essential biodiversity variables: challenges and future directions, Remote Sensing in Ecology and Conservation, DOI: 10.1002/rse2.15.

Ramananmanjato J-B., 2000, Fragmentation effects on reptile and amphibian diversity in the littoral forest of southeastern Madagascar. Zoological Monographs, 297-308, Bonn, Germany.

Ranson, K.J. and Sun, G.Q., 1994, Mapping biomass of a Northern forest using multifrequency SAR data, IEEE Transactions on Geoscience and Remote Sensing 32: 388-396.

Riitters, K.H., Coulston, J.W. and Wickham, J.D., 2003, Localizing national fragmentation statistics with forest type maps, Journal of Forestry, 101:18-22.

Rowland, C.S., H. Balzter, T.P. Dawson, A. Luckman, G. Patenaude and L. Skinner, 2008, Airborne SAR monitoring of tree growth in a coniferous plantation, International Journal of Remote Sensing 29: 3873-3889.

Rounsevell M.D.A, Dawson T.P., Harrison P.A., 2010, A conceptual framework to assess the effects of environmental change on ecosystem services, Biodiversity and Conservation 19 (10), 2823-2842.

Seppelt, R., Dormann, C.F., Eppink, F.V., Lautenbach, S. and Schmidt, S., 2011, A quantitative review of ecosystem service studies: approaches, shortcomings and the road ahead. Journal of Applied Ecology, 48, 630-636.

Shahin, A, and Mahbod, M.A., 2007, Prioritization of key performance indicators: An integration of analytical hierarchy process and goal setting, International Journal of Operations \& Production Management, 56:226-240. 
Silvestri, S., Marania, M. and Maranib, A., 2003, Hyperspectral remote sensing of salt marsh vegetation, morphology and soil topography, Physics and Chemistry of the Earth, Parts $A / B / C$, 28:1525.

Tucker, C.J., 1979, Red and Photographic Infrared Linear Combinations for Monitoring Vegetation, Remote Sensing of Environment, 8:127-150.

Turner, W., Spector, S., Gardiner, N., Fladeland, M., Sterling, E. and Steininger, M., 2003, Remote sensing for biodiversity science and conservation, Trends in Ecology \& Evolution, 18: 306-314.

UNEP/CBD/COP7, 2003, Implementation of the Strategical Plan: Evaluation of Progress towards the 2010 Biodiversity Target: Development of specific Targets, Indicators and a reporting Framework. Seventh Meeting of the Subsidiary Body on Scientific, Technical and Technological Advice to the Convention on Biological Diversity, Kuala Lumpur, pp 1-22.

Sarrazin et al. (2011), Fusing small footprint waveform lidar and hyperspectral data for canopy-level species classification and herbaceous biomass modelling in savannah ecosystems. Canadian Journal of Remote Sensing 37:653-665.

Vandewalle, M., M.T. Sykes, P.A. Harrison, G.W. Luck, P. Berry, R. Bugter, T.P. Dawson, C. Feld, R. Harrington, J.R. Haslett, D. Hering, R. Jongman, P. Martins da Silva, M. Moora, J. Paterson, M.D.A. Rounsevell, L. Sandin, J. Settele, J.P. Sousa and M. Zobel, 2008, Review paper on concepts of dynamic ecosystems and their services, Report of the RUBICODE project, EU 6th Framework programme, Contract Number: 036890. Available at:

http://www.rubicode.net/rubicode/RUBICODE_Review_on_Ecosystem_Services.pdf (last accessed on 07/04/15).

Watson, J., Whittaker, R.J. and Dawson, T.P., 2004a, Avifaunal responses to habitat fragmentation in the threatened littoral forests of south-eastern Madagascar, Journal of Biogeography, 31, 1791-1807.

Watson J, Whittaker RJ, Dawson TP. 2004b. The importance of littoral forest remnants for indigenous bird species conservation in south eastern Madagascar. Biodiversity Conservation 14: 523 - 545.

Yang, J. and Prince, S.D., 2000, Remote sensing of savanna vegetation changes in Eastern Zambia 1972-1989, International Journal of Remote Sensing, 21:301-322.

Zheng, Y., 2012, Evaluating High Resolution GeoEye-1 Satellite Imagery for Mapping Wildlife in Open Savannahs, 52 pp. International Institute for Geo-information Science and Earth Observation, University of Twente, Enschede, The Netherlands. 
Table 1. Services provided by terrestrial and freshwater ecosystems, categorized according to the MEA (adapted from Vandewalle et al., 2008).

\begin{tabular}{|c|c|c|c|c|c|c|c|c|c|c|c|}
\hline $\begin{array}{l}\text { MEA Services } \\
\text { category }\end{array}$ & Ecosystem service & $\begin{array}{c}\text { Agro- } \\
\text { ecosystems }\end{array}$ & Forests & Grasslands & $\begin{array}{l}\text { Heath/ } \\
\text { shrubs }\end{array}$ & Montane & Soils & Wetlands & $\begin{array}{l}\text { Rivers and } \\
\text { floodplains }\end{array}$ & Lakes & Marine \\
\hline \multirow[t]{6}{*}{ Provisioning } & Food, fibre and fuel & $\bullet$ & • & $\bullet$ & $\bullet$ & - & • & $\bullet$ & $\cdot$ & • & - \\
\hline & Genetic resources & $\bullet$ & $\bullet$ & $\bullet$ & $\bullet$ & $\bullet$ & & $\bullet$ & $\bullet$ & $\bullet$ & $\bullet$ \\
\hline & Biochemical/natural medicines & $\bullet$ & $\bullet$ & $\bullet$ & $\bullet$ & $\bullet$ & & & & & $\bullet$ \\
\hline & Ornamental resources & $\bullet$ & $\bullet$ & & $\bullet$ & & & & & & \\
\hline & Fresh water & & $\bullet$ & & $\bullet$ & $\bullet$ & & $\bullet$ & $\bullet$ & $\bullet$ & \\
\hline & Energy & • & & & & & & - & $\bullet$ & $\bullet$ & $\bullet$ \\
\hline \multirow[t]{12}{*}{ Regulatory } & Pollination & $\bullet$ & $\bullet$ & $\bullet$ & $\bullet$ & $\bullet$ & & & & & \\
\hline & Seed dispersal & $\bullet$ & $\bullet$ & $\bullet$ & $\bullet$ & $\bullet$ & & $\bullet$ & & & $\bullet$ \\
\hline & Pest regulation & $\bullet$ & $\bullet$ & $\bullet$ & $\bullet$ & $\bullet$ & $\bullet$ & $\bullet$ & & $\bullet$ & \\
\hline & Disease regulation & $\bullet$ & $\bullet$ & $\bullet$ & $\bullet$ & $\bullet$ & $\bullet$ & & & & \\
\hline & Climate regulation & $\bullet$ & $\bullet$ & $\bullet$ & $\bullet$ & $\bullet$ & $\bullet$ & $\bullet$ & $\bullet$ & $\bullet$ & $\bullet$ \\
\hline & Air quality regulation & $\bullet$ & $\bullet$ & & $\bullet$ & $\bullet$ & & & & & \\
\hline & Water regulation & & $\bullet$ & & $\bullet$ & $\bullet$ & • & $\bullet$ & $\bullet$ & $\bullet$ & $\bullet$ \\
\hline & Erosion regulation & $\bullet$ & $\bullet$ & $\bullet$ & $\bullet$ & $\bullet$ & $\bullet$ & & $\bullet$ & $\bullet$ & \\
\hline & Natural hazard regulation & $\bullet$ & $\bullet$ & $\bullet$ & $\bullet$ & $\bullet$ & • & $\bullet$ & $\bullet$ & & $\bullet$ \\
\hline & Invasion resistance & & $\bullet$ & $\bullet$ & • & $\bullet$ & & & $\bullet$ & & \\
\hline & Herbivory & $\bullet$ & $\bullet$ & $\bullet$ & $\bullet$ & $\bullet$ & & $\bullet$ & & & \\
\hline & Water purification/waste treatment & $\bullet$ & $\bullet$ & $\bullet$ & $\bullet$ & $\bullet$ & $\bullet$ & $\bullet$ & $\bullet$ & $\bullet$ & $\bullet$ \\
\hline \multirow[t]{7}{*}{ Cultural } & Spiritual and religious values & $\bullet$ & $\bullet$ & $\bullet$ & $\bullet$ & $\bullet$ & & $\bullet$ & $\bullet$ & $\bullet$ & $\bullet$ \\
\hline & Knowledge system & $\bullet$ & $\bullet$ & $\bullet$ & $\bullet$ & & & $\bullet$ & & & \\
\hline & Education and inspiration & $\bullet$ & $\bullet$ & $\bullet$ & $\bullet$ & $\bullet$ & & $\bullet$ & $\bullet$ & & $\bullet$ \\
\hline & Recreation and ecotourism & • & $\bullet$ & • & $\bullet$ & $\bullet$ & $\bullet$ & $\bullet$ & $\bullet$ & $\bullet$ & $\bullet$ \\
\hline & Cultural heritage & $\bullet$ & $\bullet$ & $\bullet$ & $\bullet$ & $\bullet$ & & $\bullet$ & & & $\bullet$ \\
\hline & Aesthetic values & $\bullet$ & $\bullet$ & $\bullet$ & $\bullet$ & $\bullet$ & $\bullet$ & $\bullet$ & $\bullet$ & $\bullet$ & $\bullet$ \\
\hline & Sense of place & $\bullet$ & $\bullet$ & $\bullet$ & $\bullet$ & $\bullet$ & $\bullet$ & $\bullet$ & $\bullet$ & $\bullet$ & $\bullet$ \\
\hline \multirow[t]{6}{*}{ Supporting } & Primary production & $\bullet$ & $\bullet$ & $\bullet$ & $\bullet$ & $\bullet$ & $\bullet$ & $\bullet$ & $\bullet$ & $\bullet$ & $\bullet$ \\
\hline & Photosynthesis & $\bullet$ & $\bullet$ & $\bullet$ & $\bullet$ & $\bullet$ & & $\bullet$ & $\bullet$ & - & $\bullet$ \\
\hline & Provision of habitat & • & $\bullet$ & $\bullet$ & $\bullet$ & • & • & • & • & • & • \\
\hline & Soil formation and retention & $\bullet$ & $\bullet$ & $\bullet$ & $\bullet$ & $\bullet$ & $\bullet$ & & & & \\
\hline & Nutrient cycling & $\bullet$ & $\bullet$ & $\bullet$ & $\bullet$ & $\bullet$ & $\bullet$ & $\bullet$ & $\bullet$ & $\bullet$ & $\bullet$ \\
\hline & Water cycling & $\bullet$ & $\bullet$ & $\bullet$ & $\bullet$ & $\bullet$ & - & $\bullet$ & $\bullet$ & - & \\
\hline
\end{tabular}


Table 2. Assessment criteria for indicators of biodiversity and ecosystem services (from Feld et al., 2010)

\begin{tabular}{|c|c|c|}
\hline Criteria & Example categories & Example \\
\hline $\begin{array}{l}\text { 1. Has the purpose } \\
\text { been defined? }\end{array}$ & $\begin{array}{l}\text { ecosystem quality } \\
\text { assessment; biodiversity } \\
\text { status indication; } \\
\text { environmental impact } \\
\text { assessment }\end{array}$ & $\begin{array}{l}\text { Ecosystem quality assessment is different from } \\
\text { biodiversity status indication. While the former } \\
\text { requires indicators that are compared to quality } \\
\text { reference values, the latter does not require predefined } \\
\text { quality references (unless an assessment of } \\
\text { biodiversity trends is being made). }\end{array}$ \\
\hline $\begin{array}{l}\text { 2. Is the indicator } \\
\text { type appropriate? }\end{array}$ & $\begin{array}{l}\text { status/trend; impact; } \\
\text { response indicators }\end{array}$ & $\begin{array}{l}\text { Species richness can be used to indicate and monitor } \\
\text { the status/trends of taxonomic richness of an } \\
\text { ecosystem. However, the application of species } \\
\text { richness to indicate the impact of environmental } \\
\text { stressors requires the knowledge about the kind of } \\
\text { direct linkage between richness and the stressor. }\end{array}$ \\
\hline $\begin{array}{l}\text { 3. Is the indicator } \\
\text { linked to } \\
\text { biodiversity (i) and } \\
\text { ecosystem } \\
\text { services/service } \\
\text { category (ii) }\end{array}$ & $\begin{array}{l}\text { (i) richness; genetic; } \\
\text { structural; and } \\
\text { functional biodiversity } \\
\text { (ii) provisioning; } \\
\text { regulating; supporting; } \\
\text { and cultural services }\end{array}$ & $\begin{array}{l}\text { Aquatic species richness and dominance structure may } \\
\text { be used to indicate freshwater ecosystem biodiversity. } \\
\text { If related to water quality and ecosystem integrity, the } \\
\text { indicators may also be used to indicate the service of } \\
\text { fresh water provision. }\end{array}$ \\
\hline $\begin{array}{l}\text { 4. Does the spatial } \\
\text { scale fit the } \\
\text { purpose? Is up- } \\
\text { /down-scaling } \\
\text { possible }\end{array}$ & $\begin{array}{l}\text { local to global scales; } \\
\text { indicators may be } \\
\text { applicable over a range } \\
\text { of spatial scales and } \\
\text { allow an up- } \\
\text { /downscaling of results }\end{array}$ & $\begin{array}{l}\text { Local taxon richness in grassland patches may refer to } \\
\text { several square metres, while fragmentation in the same } \\
\text { ecosystem is a measure at the landscape level and may } \\
\text { refer to several hectares or larger areas. In contrast, } \\
\text { nitrogen deposition, if normalised for area, can be } \\
\text { easily scaled up or down and thus can be applied at } \\
\text { regional, national and even global scales. }\end{array}$ \\
\hline $\begin{array}{l}\text { 5. Is a reference or } \\
\text { benchmark } \\
\text { definable? Is it } \\
\text { already applied? }\end{array}$ & yes/no to both questions. & $\begin{array}{l}\text { The trend in selected biomes, ecosystems and habitats } \\
\text { may be positive, but anyhow below a level required to } \\
\text { maintain a specific level of biodiversity. Hence, } \\
\text { biodiversity assessment requires the comparison of } \\
\text { actual results with reference/benchmark values. }\end{array}$ \\
\hline $\begin{array}{l}\text { 6. Are data / } \\
\text { sampling protocols } \\
\text { available? }\end{array}$ & yes/no to both questions & $\begin{array}{l}\text { The widespread application of indicators across } \\
\text { regions or ecosystems requires the use of comparable } \\
\text { data of a sufficient quality. Data should be collected } \\
\text { using standardized protocols }\end{array}$ \\
\hline $\begin{array}{l}\text { 7. Is remote sensing } \\
\text { applicable? }\end{array}$ & yes/no & $\begin{array}{l}\text { To compare for instance the protected area of certain } \\
\text { ecosystems or habitats, a minimum requirement is a } \\
\text { sufficient availability and resolution of spatial data. } \\
\text { This is often ensured with the application of GIS to } \\
\text { remote sensing data. For example, fragmentation } \\
\text { indices can be easily derived from aerial photographs } \\
\text { and CORINE data. }\end{array}$ \\
\hline
\end{tabular}


Table 3. Some examples of Internationally-adopted indicators using remote sensing data (adapted from Feld et al., 2010)

\begin{tabular}{|c|c|c|c|c|}
\hline No. & Indicator (references) & $\begin{array}{l}\text { Purpose(s) of } \\
\text { indication }\end{array}$ & $\begin{array}{l}\text { Indicator } \\
\text { type }\end{array}$ & $\begin{array}{l}\text { Direct/indirect link to } \\
\text { biodiversity }\end{array}$ \\
\hline 1 & $\begin{array}{l}\text { Trends in extent of biomes; } \\
\text { ecosystems and habitats } \\
\text { (UNEP/CBD/COP7 2003; } \\
\text { EEA 2007) }\end{array}$ & $\begin{array}{l}\text { assessing } \\
\text { progress } \\
\text { towards } 2010 \\
\text { target \& } \\
\text { communicate } \\
\text { trends in } \\
\text { biodiversity }\end{array}$ & status/trend & $\begin{array}{l}\text { indirect; areal } \\
\text { measure }\end{array}$ \\
\hline 2 & $\begin{array}{l}\text { Coverage of protected areas } \\
\text { (UNEP/CBD/COP7 2003; } \\
\text { EEA 2007) }\end{array}$ & $\begin{array}{l}\text { assessing } \\
\text { progress } \\
\text { towards } 2010 \\
\text { target \& } \\
\text { communicate } \\
\text { trends in } \\
\text { biodiversity } \\
\end{array}$ & status/trend & $\begin{array}{l}\text { indirect; areal } \\
\text { measure }\end{array}$ \\
\hline 3 & $\begin{array}{l}\text { Connectivity/fragmentation } \\
\text { of ecosystems } \\
\text { (UNEP/CBD/COP7 2003; } \\
\text { EEA 2007) }\end{array}$ & $\begin{array}{l}\text { assessing } \\
\text { progress } \\
\text { towards } 2010 \\
\text { target \& } \\
\text { communicate } \\
\text { trends in } \\
\text { biodiversity }\end{array}$ & $\begin{array}{l}\text { status/trend, } \\
\text { response }\end{array}$ & indirect \\
\hline 4 & $\begin{array}{l}\text { Normalized Differenced } \\
\text { Vegetation Index NDVI } \\
\text { (Ares et al. 2001) }\end{array}$ & $\begin{array}{l}\text { indication of } \\
\text { management } \\
\text { and disturbance }\end{array}$ & status & indirect \\
\hline 5 & $\begin{array}{l}\text { Forest fragmentation } \\
\text { (Riitters et al. 2003) }\end{array}$ & $\begin{array}{l}\text { fragmentation } \\
\text { status } \\
\text { assessment }\end{array}$ & status/trend & indirect \\
\hline 6 & $\begin{array}{l}\text { Share of semi-natural } \\
\text { habitat (Billeter } \text { et al. 2008) }\end{array}$ & $\begin{array}{l}\text { indication of } \\
\text { management } \\
\text { and disturbance }\end{array}$ & status & $\begin{array}{l}\text { indirect; areal } \\
\text { measure }\end{array}$ \\
\hline
\end{tabular}


Table 4: Selected current and future Earth Observation missions which have the potential to provide landscape indicators of biodiversity and associated ecosystem services (Adapted from O'Connor et al., 2015)

\begin{tabular}{|c|c|c|c|c|}
\hline Satellite & Sensor & $\begin{array}{l}\text { Spatial; spectral; } \\
\text { temporal resolution* }\end{array}$ & $\begin{array}{l}\text { Launch / } \\
\text { expected } \\
\text { launch date }\end{array}$ & $\begin{array}{l}\text { Example ecosystem } \\
\text { services / landscape } \\
\text { indicators }\end{array}$ \\
\hline Landsat-8 & $\begin{array}{l}\text { Multispectral } \\
\text { Imager }\end{array}$ & $\begin{array}{l}15-30 \mathrm{~m} ; 9 \\
\text { wavebands; } 16 \text { days }\end{array}$ & Feb. 2013 & \multirow{3}{*}{$\begin{array}{l}\text { Global assessment of } \\
\text { land cover, extent of } \\
\text { biomes, ecosystems and } \\
\text { habitats; plant status and } \\
\text { health; Ecosystem } \\
\text { fragmentation and } \\
\text { connectivity; NDVI and } \\
\text { other vegetation indices; } \\
\text { primary production; } \\
\text { erosion monitoring. }\end{array}$} \\
\hline WorldView-3 & $\begin{array}{l}\text { Multispectral } \\
\text { imager }\end{array}$ & $\begin{array}{l}9 \text { wavebands } \\
\text { (VNIR); } 0.31-1.3 \\
\text { m; } 1-4 \text { days }\end{array}$ & August 2014 & \\
\hline Sentinel-1 & $\begin{array}{l}\text { Multispectral } \\
\text { Imager }\end{array}$ & $\begin{array}{l}10-60 \mathrm{~m} ; 13 \\
\text { wavebands; } 5 \text { days }\end{array}$ & June 2015 & \\
\hline EnMap & $\begin{array}{l}\text { Hyperspectral } \\
\text { imager }\end{array}$ & $\begin{array}{l}30 \mathrm{~m} ; 244 \\
\text { wavebands; } 4 \text { days }\end{array}$ & 2018 & \multirow{2}{*}{$\begin{array}{l}\text { Global assessment of } \\
\text { plant biophysical and } \\
\text { biochemical content; } \\
\text { pest and disease } \\
\text { detection; vegetation } \\
\text { species mapping; } \\
\text { mineral mapping; } \\
\text { erosion monitoring. }\end{array}$} \\
\hline HYSPIRI & $\begin{array}{l}\text { Hyperspectral } \\
\text { Imager }\end{array}$ & $\begin{array}{l}60 \mathrm{~m} ; 19 \text { days; } 0.3- \\
12 \mu \mathrm{m}\end{array}$ & 2022 & \\
\hline Alos-2 & L-Band Radar & $10 \mathrm{~m} ; 14$ days & May 2014 & \multirow{3}{*}{$\begin{array}{l}\text { Global assessment of } \\
\text { forest cover and } \\
\text { fragmentation and } \\
\text { disturbance; status and } \\
\text { trends in above ground } \\
\text { biomass; soil moisture; } \\
\text { land cover mapping; } \\
\text { topographic change. }\end{array}$} \\
\hline Sentinel-2 & C-Band SAR & 5-20 m; 6 days & April 2014 & \\
\hline $\begin{array}{l}\text { BIOMASS } \\
2020\end{array}$ & P-Band SAR & $50 \mathrm{~m}$ & 2020 & \\
\hline ICESat-2 & Laser altimeter & 91 day repeat cycle & 2017 & $\begin{array}{l}\text { Global assessment of } \\
\text { vegetation height at } 1 \mathrm{~km} \\
\text { resolution. }\end{array}$ \\
\hline
\end{tabular}

* If available at the time of publication 


\section{Figures}

Figure 1. Satellite-derived map of forest fragmentation and degradation in south eastern Madagascar (from Ingram et al., 2005a).

Figure 2. Utilitarian versus non-use species of trees for 22 transects surveyed in the fragmented forests of southeast Madagascar (from Ingram et al., 2005b).

Figure 3. Relationships between AIRSAR backscattering coefficient and above-ground biomass density.

Figure 4: Extract of land cover map derived from pan-sharpened WorldView-2 imagery, illustrating areas of bare peat and water.

Figure 5: Mean patch area (a), and patch density (b) per $1 \mathrm{~km}$ grid cell, derived from mapped areas of bare peat in the WorldView-2 image land cover classification. Areas in red have a higher mean patch area and higher patch density, indicating greater fragmentation and areas of bare peat.

Figure 6: (a) Extract of pan-sharpened WorldView-2 image; (b) supervised land cover classification; and(c) potential erosion risk derived from a knowledge-based classification incorporating image texture, lineament detection, land cover and a digital elevation model. 


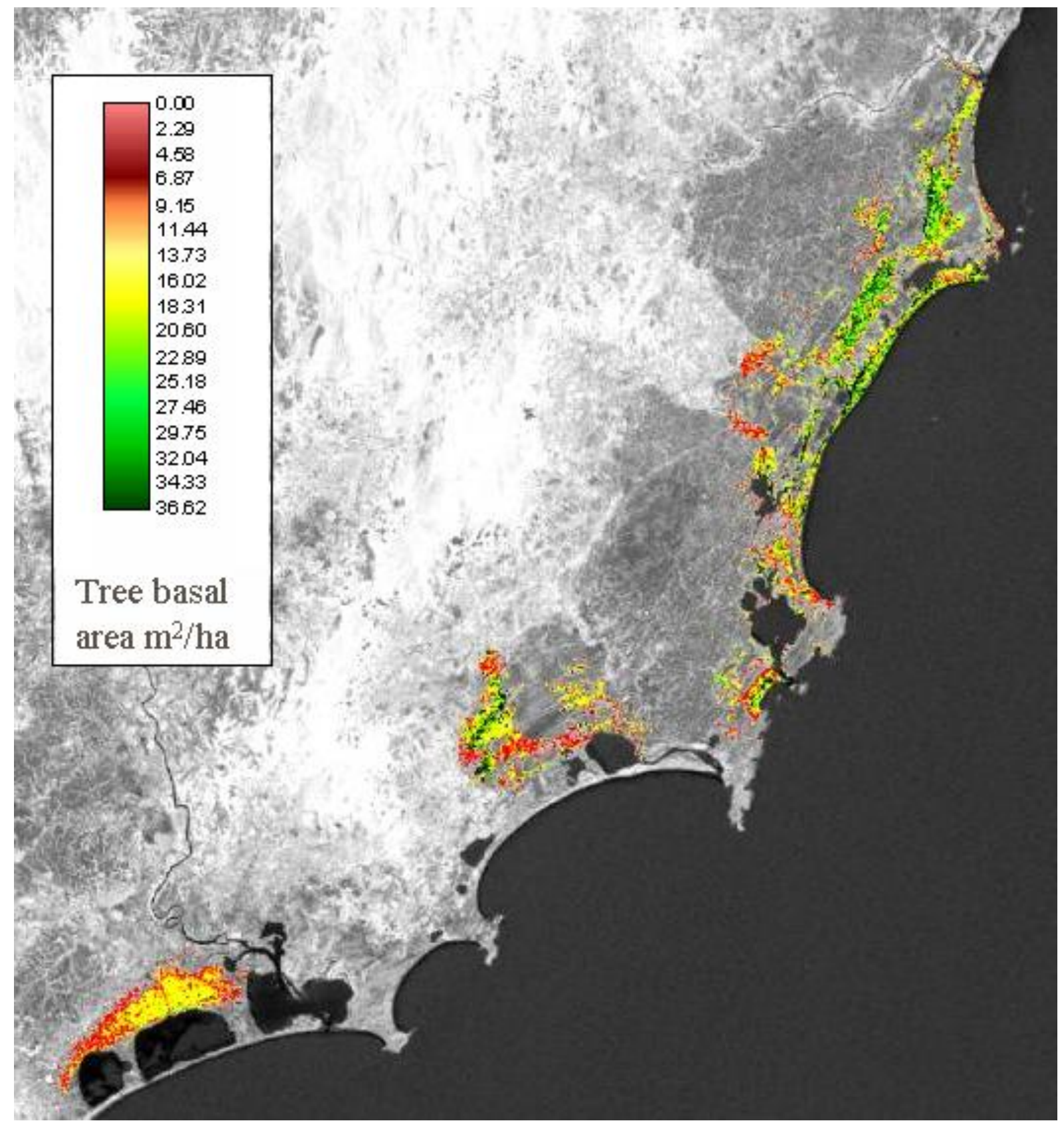

Figure 1. Satellite-derived map of forest fragmentation and degradation in south eastern Madagascar (from Ingram et al., 2005a). 


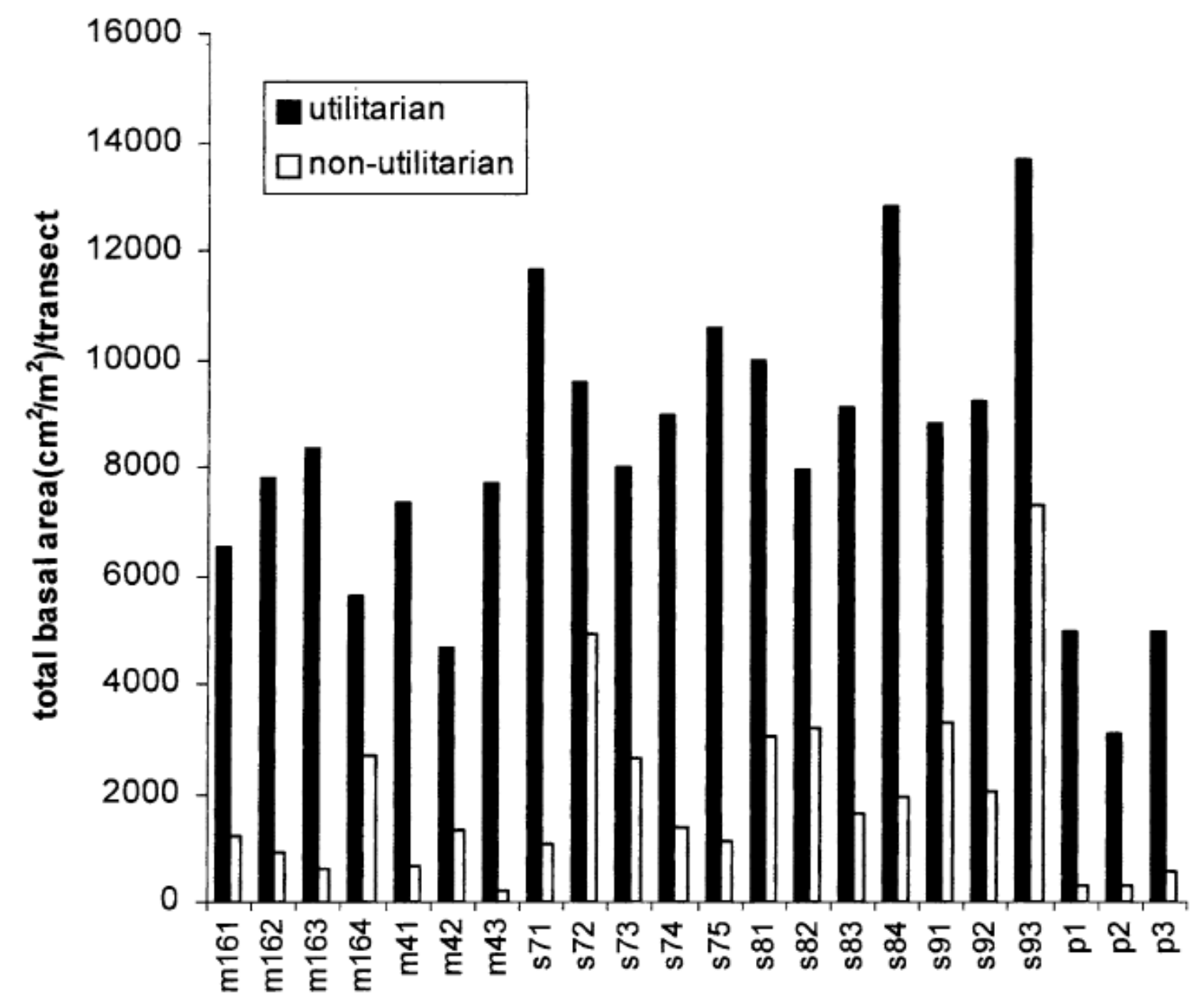

Figure 2. Utilitarian versus non-use species of trees for 22 transects surveyed in the fragmented forests of southeast Madagascar (from Ingram et al., 2005b). 


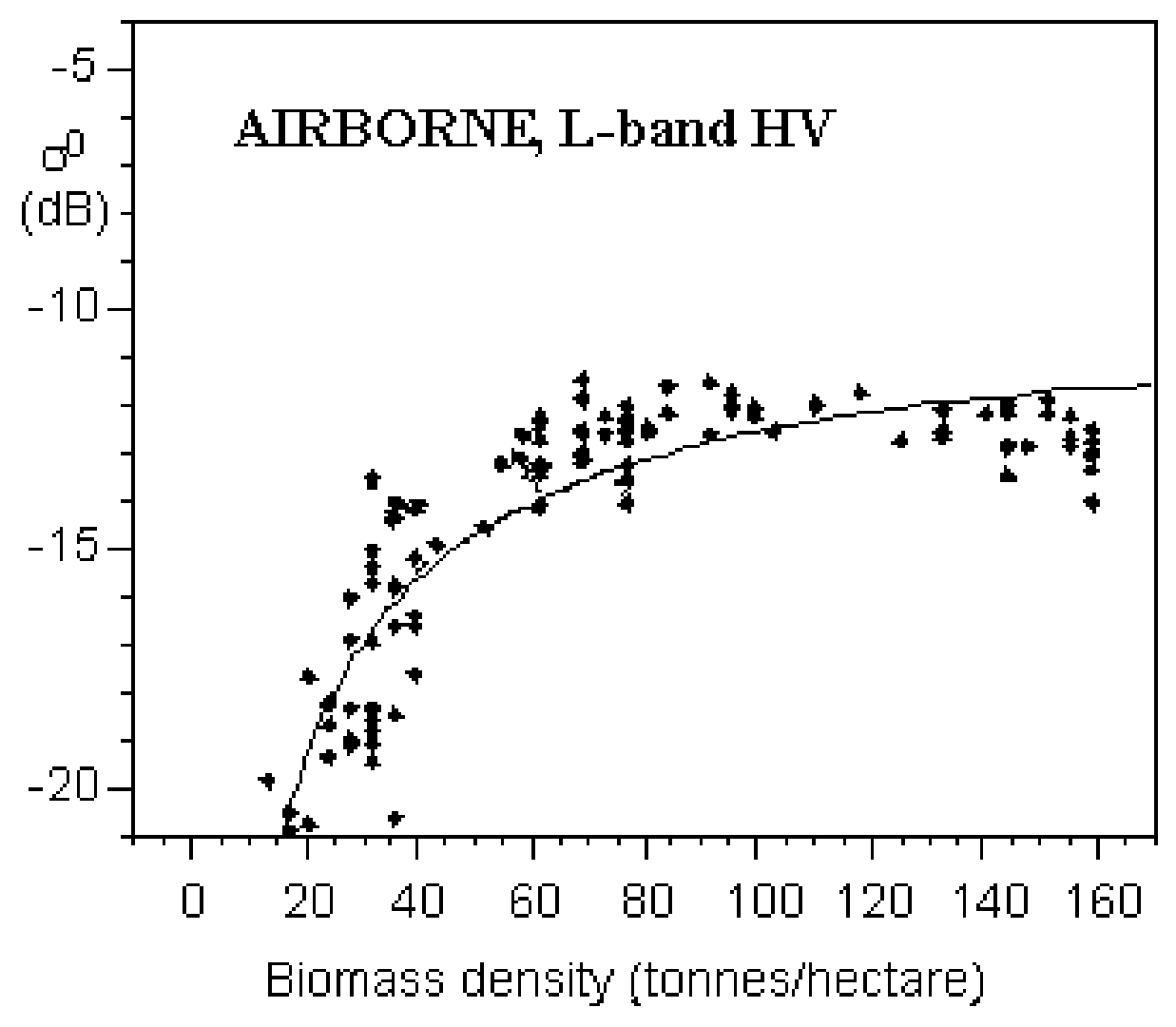

Figure 3. Relationships between AIRSAR backscattering coefficient and above-ground biomass density. 


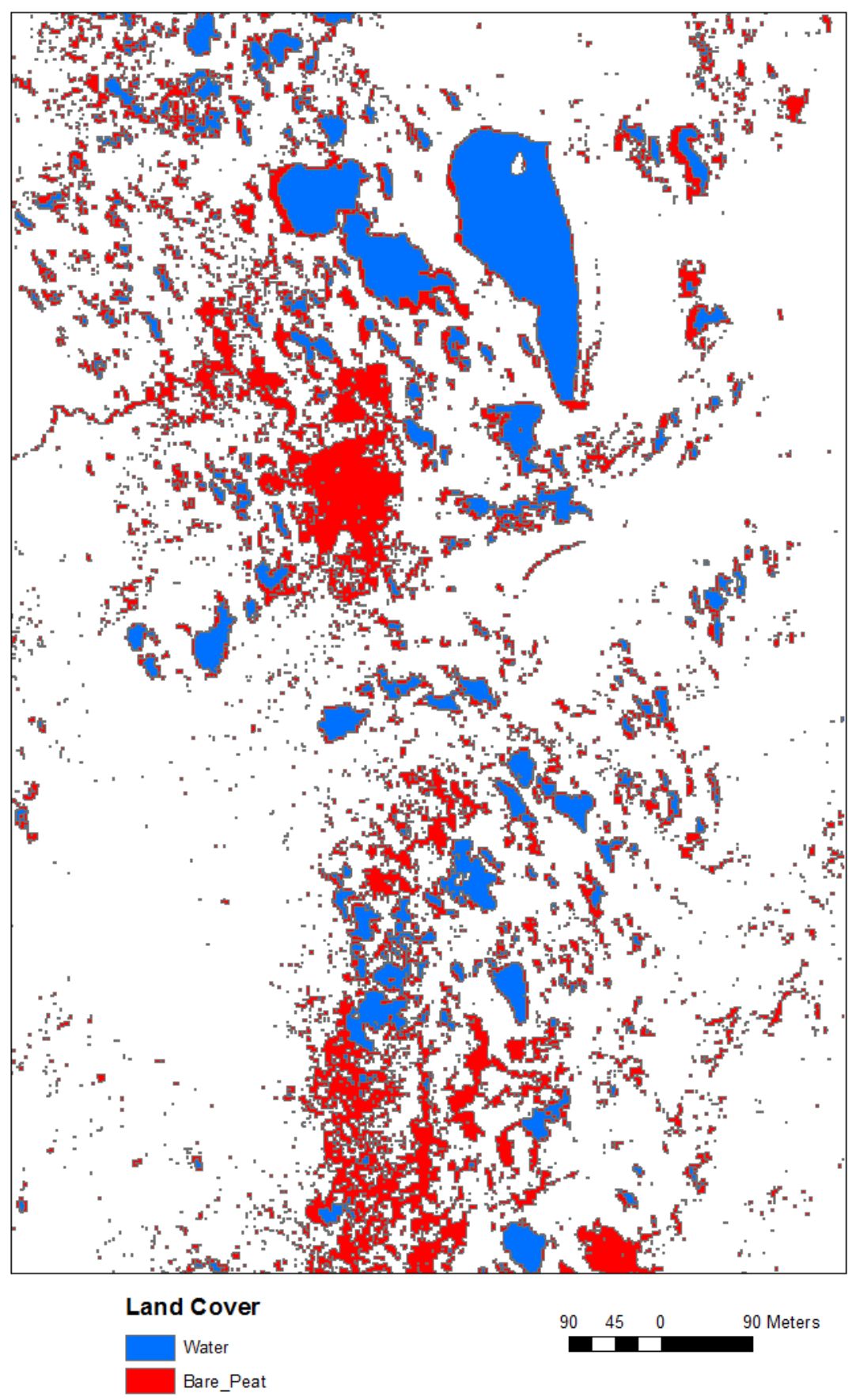

Figure 4: Extract of land cover map derived from pan-sharpened WorldView-2 imagery, illustrating areas of bare peat and water. 

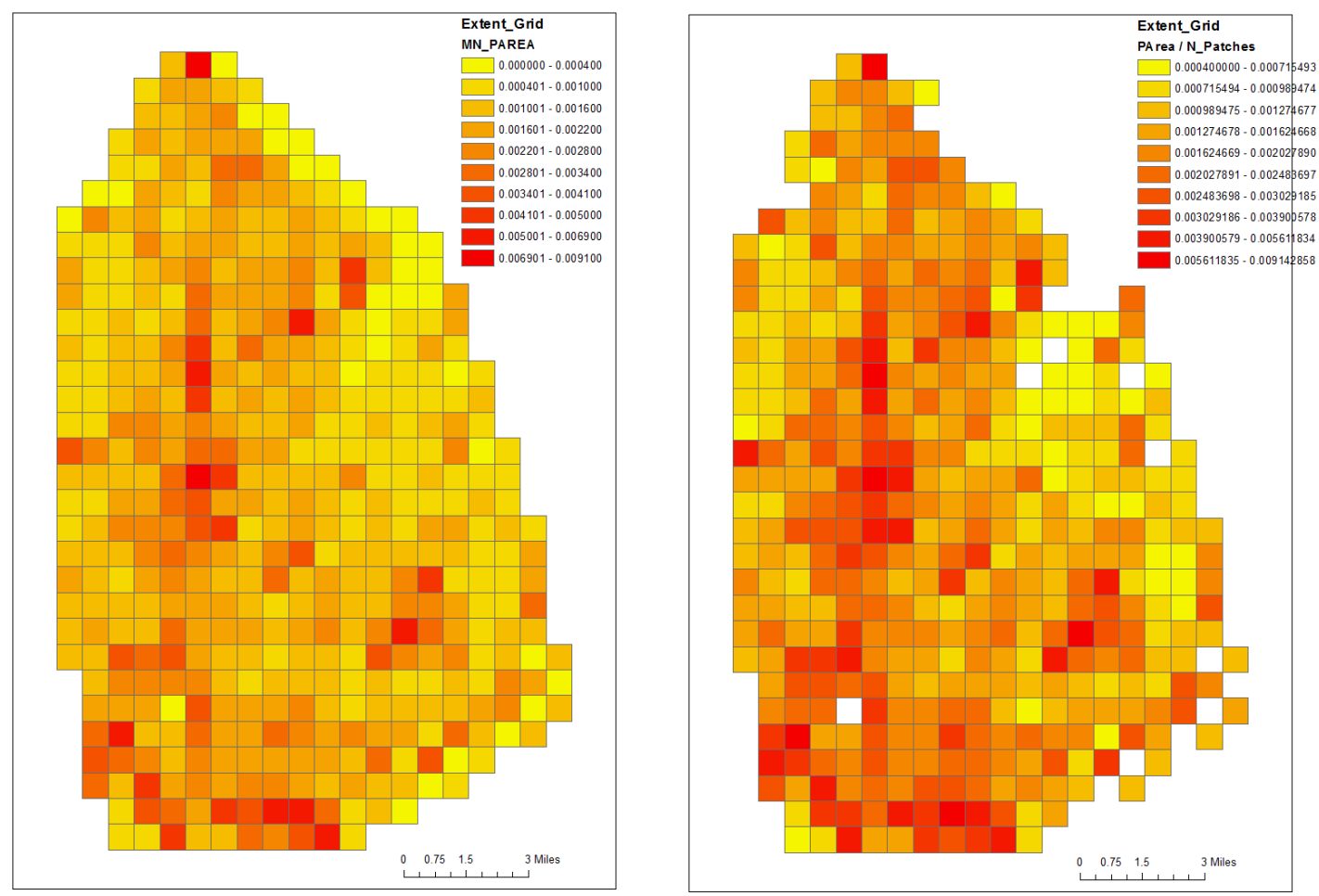

Figure 5: Mean patch area (a), and patch density (b) per $1 \mathrm{~km}$ grid cell, derived from mapped areas of bare peat in the WorldView-2 image land cover classification. Areas in red have a higher mean patch area and higher patch density, indicating greater fragmentation and areas of bare peat. 


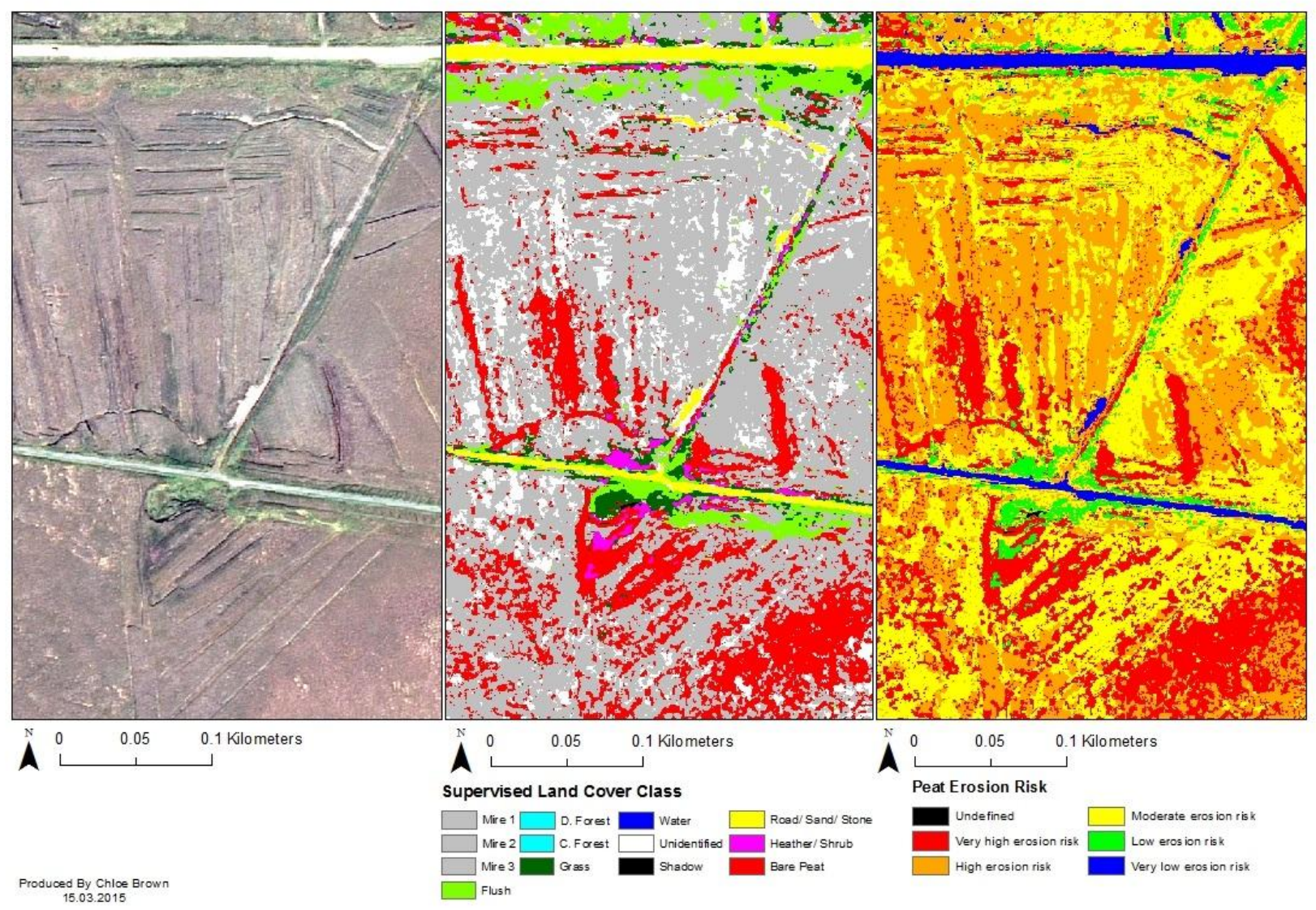

Figure 6: (a) Extract of pan-sharpened WorldView-2 image; (b) supervised land cover classification; and(c) potential erosion risk derived from a knowledge - based classification incorporating image texture, lineament detection, land cover and a digital elevation model. 